\title{
Kualitas Produk, Kesadaran Merek dan Harga serta Pengaruhnya Terhadap Kepuasan Pelanggan
}

\author{
Didit Darmawan \\ Program Studi Manajemen, Fakultas Ekonomi, Universitas Mayjen Sungkono Mojokerto \\ Email: dr.diditdarmawan@gmail.com
}

\begin{abstract}
The growing of restaurant industry is causing high competition among business competitor, each business is required to create competitive advantage to satisfy customers and increase the level of sales. Business people in this industry strive to achieve maximum satisfaction for their customers and not only to achieve profits. This is because satisfied customers will determine the sustainability of the relationship with the restaurant. Every effort should be made to get satisfied customers with restaurant services. This study aims to analyze and discuss the influence of product quality, brand awareness and price on customer satisfaction in Dewi Kahyangan restaurant in Jombang City. The three independent variables involved in this study are product quality, brand awareness and price. One dependent variable is customer satisfaction. The research method used was qualitative. The sampling technique used wasnon-probability sampling. The population in this research all custumes who had eaten at the Dewi Kahyangan restaurant in Jombang City, with 100 respondents of sample size.The technique for taking samples is used non probability sampling techniques with accidental sampling method. The analytical tool used was multiple linearregression with SPSS 24.0 for windows. The results showed that product quality, brand awareness and price had a significant partial and simultaneous effect on customer satisfaction.
\end{abstract}

\begin{abstract}
Abstraksi: Perkembangan industri rumah makan yang semakin meningkat menyebabkan tingginya persaingan antar pelaku bisnis, masing-masing pelaku bisnis dituntut mampu menciptakan keunggulan bersaing untuk memuaskan pelanggan dan meningkatkan tingkat penjualan. Pelaku di industri ini berusaha untuk mencapai kepuasan bagi pelanggannya secara maksimal dan bukan hanya untuk mencapai keuntungan. Hal ini karena pelanggan yang puas akan menentukan keberlanjutan hubungan dengan pihak rumah makan. Segala upaya seharusnya dilakukan untuk memperoleh pelanggan-pelanggan yang puas terhadap layanan rumah makan. Penelitian ini bertujuan untuk menganalisis dan mengetahui pengaruh kualitas produk, kesadaran merek dan harga terhadap kepuasan pelanggan rumah makan Dewi Kahyangan di Kota Jombang. Tiga variabel bebas yang terlibat di penelitian ini adalah kualitas produk, kesadaran merek dan harga. Satu variabel terikat adalah kepuasan pelanggan. Metode penelitian yang digunakan adalah kualitatif. Teknik pengambilan sampel menggunakan non probability sampling. Populasi pada penelitian ini adalah seluruh pelanggan yang pernah makan di rumah makan Dewi Kahyangan di Kota Jombang, dengan jumlah sampel sebanyak 100 responden. Teknik untuk mengambil sampel digunakan teknik non probability sampling dengan metode accidental sampling. Alat analisis yang digunakan yaitu regresi linier berganda dengan bantuan software SPSS 24.0 for windows. Hasil penelitian menunjukan bahwa kualitas produk, kesadaran merek dan harga berpengaruh parsial dan simultan secara signifikan terhadap kepuasan pelanggan.
\end{abstract}

Keywords: Product Quality; Brand Awareness; Price; Customer Satisfaction

\section{Pendahuluan}

Setiap pengusaha berusaha memperoleh profit dan mempertahankan bisnisnya untuk jangka waktu yang lama. Usaha yang dimulai dari skala kecil dapat berkembang menjadi lebih besar dan tersebar di berbagai lokasi karena respon pasar yang baik terhadap produk yang ditawarkannya. Menurut Belohlav (1993) dan Carr (1995) perusahaan secara terus menerus berfokus terhadap peningkatan kualitas produk karena akan memberikan kekuatan ketika menghadapi persaingan, meningkatkan kesuksesan dan memberikan produk yang berbeda dengan pesaing. Hal tersebut menunjukkan bahwa kualitas produk memiliki peran paling penting pada daya saing di dunia bisnis (Chaudhuri, 2002).

Fenomena bermunculannya rumah makan dengan merek-merek baru telah menunjukkan berkembangnya industri rumah makan. Kegiatan pemasaran untuk 
mengembangkannya perlu didukung dengan kehandalan sumber daya manusia sebagai wujud layanan yang dapat memenuhi harapan para pelanggannya.

Rumah makan atau restoran adalah suatu bisnis di bidang tata boga yang berhubungan dengan makanan dan minuman yang nikmat serta memberikan hidangan kepada seseorang atau beberapa kelompok, ada tarif makanan dan layanan yang ditetapkan, dikendalikan secara profesional dan mencari keuntungan serta kepuasan pelanggan sebagai tujuannya. Hidangan yang berkualitas seperti aroma, makanan yang beragam, makanan yang sehat, segar dan bergizi akan memberikan kepuasan (Ryu et al., 2012). Pernyataan tersebut juga didukung dengan hasil penelitian dari Qin dan Prybutok (2009); Ha dan Jang (2010) bahwa makanan yang berkualitas memiliki pengaruh yang positif terhadap kepuasan. Selain makanan yang berkualitas, presentasi penyajian makanan seperti hiasan yang menarik juga dapat memberikan kepuasan (Namkung dan Jang, 2007).

Hal tersebut menunjukkan bahwa kepuasan pelanggan menjadi hal yang paling penting pada suatu bisnis kuliner karena kepuasan pelanggan untuk meningkatkan tingkat penjualan dan mengurangi sensitivitas pelanggan terhadap harga yang ditetapkan. Pernyataan tersebut juga sesuai menurut Deng et al. (2009) yang berpendapat bahwa pelanggan yang puas sebagai salah satu sumber pendapatan yang penting di dunia bisnis. Para pelaku bisnis harus dapat memenangkan hati para pelanggannya dan harus memfokuskan pada upaya mempertahankan pelanggan secara stabil dengan cara menerapkan peninjauan dan penilaian terhadap kepuasan pelanggan. Melalui observasi pelanggan yang dilakukan dengan stabil diharapkan ada umpan balik yang diberikan pelanggan untuk mengembangkan dan mengimplementasikan kepuasan pelanggan di waktu yang akan datang.

Selain itu, aset utama penentu berhasil atau tidaknya rumah makan akan sangat ditentukan oleh pelanggan karena pelanggan memiliki potensi sebagai penentu pertumbuhan dan peningkatan loyalitas di masa depan. Pelanggan yang berhasil dipertahankan akan menjadi jaminan terhadap keberlangsungan hidup bisnis rumah makan. Oleh karena itu perlu diperhatikan variabel-variabel apa saja yang akan menentukan pelanggan menjadi puas terhadap layanan yang disampaikan oleh pihak rumah makan.

Variabel kualitas produk sebagai salah satu variabel yang dapat memberikan pengaruh terhadap kepuasan pelanggan. Produk yang berkualitas dapat dilihat dari seberapa besar totalitas fiturnya, karakteristik produk atau layanan yang mampu memberikan kepuasan (Chavan, 2003). Akrani (2013) juga mendukung pernyataan sebelumnya bahwa produk yang mampu untuk memenuhi, memberikan rasa puas dan sesuai dengan apa yang diinginkan pelanggan adalah produk yang berkualitas. Pernyataan sebelumnya juga sesuai dengan pendapat Eduardo et al. (2008) bahwa kualitas produk sebagai langkah awal tercapainya kepuasan dan loyalitas. Oleh sebab itu, kualitas produk mempengaruhi kepuasan pelanggan.

Tidak hanya dilihat dari kualitas produk, kesadaran merek dan harga ternyata juga memberikan pengaruh terhadap kepuasan pelanggan karena apa yang menjadi pilihan pelanggan dipengaruhi oleh kesadaran merek (Hoyer dan Brown, 1990; Srinivasan et al., 2005; Farris et al., 2010). Kesadaran merek memberikan informasi tentang suatu produk (Homburg et al., 2010) dan kesadaran merek sebagai penentu pembelian (Černikovaite, 2011). Hoffman dan Fodor (2010) menjelaskan pelanggan yang puas dan loyal akan memberikan informasi tentang merek yang dibeli melalui metode word of mouth sehingga kesadaran merek akan meningkat.

Harga lebih dari sebuah angka karena harga sebagai penentu keputusan penjual atau pembeli untuk memberikan atau memperoleh informasi. Harga sebagai penentu keputusan pembelian (Khan, 2011) dan penentu pengalaman terhadap produk atau layanan (Mattila dan O'Neill, 2003). Menurut Andaleeb dan Conway (2006) harga sebagai biaya yang berhubungan dengan layanan yang diberikan oleh rumah makan. Harga 
yang dipersepsikan pelanggan juga memberikan pengaruh terhadap kepuasan pelanggan (Varki dan Colgate, 2001).

Berdasarkan uraian latar belakang sebelumnya maka topik yang menarik perhatian peneliti, yaitu "Kualitas Produk, Kesadaran Merek dan Harga serta Pengaruhnya Terhadap Kepuasan Pelanggan". Penelitian ini akan mengkaji tiga variabel bebas, yaitu kualitas produk, kesadaran merek, harga yang menentukan kepuasan pelanggan.

Penelitian ini merumuskan masalah seperti berikut: (a) apakah kualitas produk memiliki pengaruh yang signifikan terhadap kepuasan pelanggan? (b) apakah kesadaran merek memiliki pengaruh yang signifikan terhadap terhadap kepuasan pelanggan? (c) apakah harga memiliki pengaruh yang signifikan terhadap kepuasan pelanggan? (d) apakah kualitas produk, kesadaran merek dan harga memiliki pengaruh simultan yang signifikan terhadap kepuasan pelanggan?

Berdasarkan rumusan masalah yang telah disebutkan sebelumnya maka tujuan penelitian ini, yaitu untuk menganalisis dan mengetahui (a) pengaruh kualitas produk terhadap kepuasan pelanggan; (b) pengaruh kesadaran merek terhadap kepuasan pelanggan; (c) pengaruh harga terhadap kepuasan pelanggan; dan (d) pengaruh kualitas produk, kesadaran merek dan harga secara simultan terhadap kepuasan pelanggan.

\section{Kajian Teori}

\section{Kualitas Produk}

Secara umum kualitas sebagai bagian terpenting dari keunggulan bersaing sehingga bagaimana meningkatkan kualitas produk telah menjadi permasalahan utama di setiap perusahaan (Flynn et al., 1995; Yuen dan Chan, 2010). Pada pemasaran kualitas produk dianggap sebagai faktor penentu keputusan pembelian dan kepuasan pelanggan, jika suatu produk dinilai baik maka produk tersebut dapat dirasakan secara positif. Jahanshahi et al. (2011) menjelaskan produk yang berhasil memenuhi harapan pelanggan maka berpotensi untuk memberikan rasa puas, senang, menilai produknya dapat diterima dan memiliki kualitas yang tinggi. Saleh (2008) menyatakan bahwa pengawasan secara maksimal terhadap produk yang berkualitas maka akan berpengaruh terhadap peningkatan kepuasan dan loyalitas. Kepuasan dapat meningkat ketika kualitas produk dan pengawasan kualitas dilakukan dengan tepat (Flavio et al., 2009; Verhoef dan Lemon, 2013).

Setiap konsumen pada akhirnya akan membuat keputusan tentang kualitas selama atau setelah menggunakan produk. Hal ini menunjukkan bahwa kualitas tidak hanya diukur berdasarkan terpenuhinya spesifikasi, kerusakan dan variasi yang minimal tetapi lebih pada bagaimana keandalan produknya (Xu et al., 2013). Kualitas produk juga berpengaruh positif terhadap segmen pasar (Tellis et al., 2009a, 2009b). Pernyataan tersebut mendukung bahwa kualitas mempengaruhi kepuasan, nilai pelanggan yang tinggi (Bolton, 1998; Hogan et al., 2002; Fetscherin dan Toncar, 2009; Verhoef dan Lemon, 2013).

Reputasi perusahaan yang baik tentu akan menunjukkan kualitas produk yang unggul (Wolf, 1986; Fetscherin dan Toncar, 2009). Kualitas produk atau layanan yang tinggi dapat meningkatkan reputasi, retensi, mempengaruhi pelanggan baru, kinerja dan keuntungan (Zeithaml, 1996). Kualitas produk memberikan kontribusi terhadap keunggulan yang bersaing sehingga produk harus dipersiapkan, diproduksi untuk meningkatkan kinerja produk dan memenuhi harapan pelanggan (Benson et al., 1991; Flynn et al., 1994).

Kualitas produk yang ditingkatkan harus diarahkan pada pencapaian peningkatan kepuasan pelanggan dan penjualan (Smith dan Wright, 2004). Evaluasi terhadap kualitas produk dapat disesuaikan dengan bagaimana pelanggan menilai manfaat produk dan perasaan subjektif terhadap kualitas yang diberikan (Dodds et al., 1991). Hilgenkamp dan Shanteau (2010) menyatakan kualitas produk berhubungan 
dengan nama merek yang memberikan pengaruh terhadap evaluasi pelanggan dan kekuatan merek.

Ada beberapa penjelasan tentang kualitas produk, diantaranya (1) Walter et al. (2002) menyatakan kualitas produk sebagai evaluasi terhadap karakteristik kualitas yang terdiri dari daya tahan, fungsi, kendalan serta dilakukan terhadap produk yang telah dibeli; (2) Smith dan Wright (2004) mengemukakan kualitas produk adalah ketersediaan produk yang memiliki tujuan untuk memenuhi harapan pelanggan; (3) kualitas produk merupakan semua kualitas atau produk yang unggul dan sesuai dengan harapan para pelanggan (Kotler dan Keller, 2009); (4) Ndukwe (2011) menjelaskan bahwa kualitas produk adalah karakteristik dari suatu produk yang memberikan kepuasan terhadap apa yang diinginkan dan dibutuhkan oleh pelanggan. Ada delapan indikator untuk mengukur kualitas produk (Garvin, 1987) yaitu, (1) performance; (2) features; (3) reliability; (4) conformance; (5) durability; (6) service ability; (7) aesthetics; dan (8) fit and finish.

\section{Kesadaran Merek}

Salah satu dari tujuan utama setiap bisnis adalah untuk membangun kesadaran merek bagi pelanggan sangat dipengaruhi dari rekomendasi pengalaman langsung (Darmawan, 2014). Kesadaran merek dipengaruhi oleh beberapa merek yang dipertimbangkan pelanggan (Mcdonald dan Sharp 2000). Pertimbangan yang dilakukan sebagai langkah awal untuk keputusan pembelian. Keputusan yang diambil pelanggan terhadap suatu produk cenderung cepat bila mereka telah mengenal dan memahami merek rumah makan tersebut.

Pendapat dari pelanggan dipengaruhi oleh kesadaran merek karena mereka akan bertindak berdasarkan informasi yang penting ketika mengambil keputusan (Salancik dan Conway, 1975; Pryor dan Kriss, 1977). Salah satu faktor yang dapat memberikan pengaruh terhadap tingkat pengetahuan konsumen terhadap merek adalah kesadaran merek (Ekhveh dan
Darvishi, 2015). Kesadaran merek mengarah pada penjualan yang meningkat karena kecenderungan merek yang difikirkan pelanggan (Hoeffler dan Keller, 2002) sehingga memberikan kontribusi terhadap nilai mereka (Berry 2000). Disinilah rumah makan akan memperoleh keuntungan yang diinginkan karena pada tahap ini pelanggan tidak memperhatikan harga dari produknya karena mereka percaya pada suatu merek. Kesadaran merek dapat meningkat karena adanya pelanggan (Keller, 2001).

Ada beberapa penjelasan tentang kesadaran merek, diantaranya (1) Rossiter dan Percy (1987) menjelaskan kesadaran merek sebagai kemampuan mengingat merek yang ditunjukkan dengan pelanggan yang mampu mengidentifikasi merek pada kondisi yang beragam; (2) Percy dan Rossiter (1992) mengatakan kesadaran merek adalah pembeli yang mampu untuk mengingat merek produknya; (3) kesadaran merek adalah seorang calon pembeli yang bersedia mengetahui dan tidak melupakan suatu merek (Aaker, 1997); (4) Farhana (2012) menjelaskan kesadaran merek sebagai kekuatan merek yang dapat diingat pelanggan dan kemampuan untuk mengenali bagian merek (label merek, bagaimana desain logo, lambang, karakter, kemasan dan slogan); (5) kesadaran merek ialah pengenalan merek yang berpotensi untuk diingat dan memberikan informasi, ide dari suatu produk (Bilgili dan Ozkul, 2015). Ada tiga indikator menurut Aaker (1997) untuk mengukur kesadaran merek para pelanggan, yaitu, (1) keahlian mengenali merek; (2) keahlian untuk mengenali bentuk yang beragam; dan (3) ciri khusus merek (menguasai informasi tentang merek).

\section{Harga}

Harga sebagai salah satu sumber daya yang bermanfaat untuk memperluas keuntungan dan kepuasan pelanggan (Huber et al., 2001). Salah satu faktor yang berperan penting ketika pelanggan memilih atau merasakan suatu produk adalah harga (Kotler dan Armstrong. 2012). Pernyataan dari Kotler dan Armstrong (2012) juga didukung oleh Soderlund (2000) yang menyatakan 
bahwa produk yang dipilih pelanggan salah satunya ditentukan okeh faktor harga.

Hal tersebut menunjukkan bahwa harga sebagai salah satu alasan untuk memilih merek karena ketika memilih harga terendah maka secara tidak langsung telah menghindari risiko keuangan dan bersedia memilih produk dengan harga tinggi karena sesuai dengan kualitasnya (Macdonald dan Sharp, 2000). Pelanggan dapat memperoleh harga yang diharapkan ketika membandingkan harga dengan kepuasan yang diperoleh (Oliver, 1980). Harga yang berkualitas sebagai penentu kepuasan pelanggan (Margee dan Mort, 2008). Ketika para pelanggan percaya bahwa harga suatu produk adil, akan menimbulkan kecenderungan para pelanggan untuk membeli ulang suatu produk tersebut. Sebaliknya, pelanggan yang merasakan bahwa tidak ada kesesuaian antara suatu produk dan harga maka tidak ada keinginan untuk membeli kembali produk tersebut "kewajaran harga" yang dipelopori memiliki korelasi yang positif terhadap retensi pelanggan (Ranaweera dan Neely, 2003).

Harga adalah sejumlah uang yang dibayarkan oleh pelanggan untuk memperoleh produk yang telah ditawarkan (Kotler dan Keller, 2009). Ada empat indikator yang mencirikan harga (Bhattacharya dan Friedman, 2001) yaitu, (1) harga yang dapat dijangkau ; (2) ada kecocokan antara harga dengan kualitas produknya; (3) daya saing harga; dan (4) kecocokan harga dengan manfaat yang diperoleh.

\section{Kepuasan pelanggan}

Kepuasan pelanggan terbentuk ketika masa pembelian, pengalaman yang dirasakan setelah membeli dan menggunakan produk tersebut (Darmawan, 2014). Kepuasan sebagai kombinasi dari pembelajaran pelanggan dan pengalaman sebelumnya sehingga ada klarifikasi setelah pembelian (Westbrook dan Oliver, 1981). Hal tersebut menunjukkan bahwa pengalaman setelah mengkonsumsi dapat memberikan pengaruh terhadap kepuasan pelanggan (Ajzen dan
Fishbein, 1980; Oliver, 1980). Kepuasan pelanggan juga dapat mempengaruhi intensi pembelian ulang pelanggan (Oliver dan Bearden, 1983). Kepuasan pelanggan dapat menjadi penilaian terhadap bagaimana fitur produk atau layanan yang diberikan atau disediakan apakah dapat memenuhi harapan pelanggan sehingga menimbulkan rasa senang (Hunt, 1971; Oliver, 1997) atau justru melebihi apa yang diharapakan pelanggan (Oliver, 1997).

Ada beberapa penjelasan tentang kepuasan pelanggan, diantaranya (1) rasa senang atau kecewa yang dirasakan dari kinerja suatu produk (Kotler dan Keller, 2009); (2) Hui dan Zheng (2010) menjelaskan kepuasan pelanggan adalah hasil kualitas yang dirasakan akibat penilaian secara evaluatif terhadap transaksi; (3) Santouridis dan Trivellas (2010) menyatakan kepuasan pelangan sebagai sejauh mana harapan pelanggan dapat terpenuhi karena kinerja layanan yang diberikan. Ada lima indikator kepuasan pelanggan menurut Kotler dan Keller (2009), yaitu, (1) bersedia tetap bertahan untuk jangka waktu yang lebih lama; (2) bersedia membeli kembali ketika rumah makan memberikan penawaran produk terbarunya dan produk yang telah diperbaiki; (3) menjelaskan hal-hal baik kepada orang lain yang berhubungan dengan rumah makan dan produknya; (4) tidak menanggapi merek pesaing dan tidak seberapa responsif terhadap harga; dan (5) merekomendasikan ide produk kepada rumah makan.

\section{Kerangka Konseptual}

Ada tiga variabel bebas yang ditetapkan pada penelitian ini, yaitu kualitas produk (X1), kesadaran merek (X2) dan harga (X3) dan satu variabel terikat, yaitu kepuasan pelanggan $(\mathrm{Y})$. Berdasarkan hasil penelitian dari (a) kualitas produk memiliki pengaruh yang signifikan terhadap kepuasan pelanggan (Jahanshahi et al., 2011; Razak, 2016; Hoe dan Mansori, 2018); (b) kesadaran merek memiliki pengaruh yang signifikan terhadap terhadap kepuasan pelanggan (Bilal dan Malik, 2014; Poranki, 2015); (c) harga memiliki pengaruh yang signifikan terhadap 
kepuasan pelanggan (Malik et al., 2012; Bilal dan Malik, 2014; Foster, 2016); dan (d) kualitas produk, kesadaran merek dan harga memiliki pengaruh simultan yang signifikan terhadap kepuasan pelanggan.

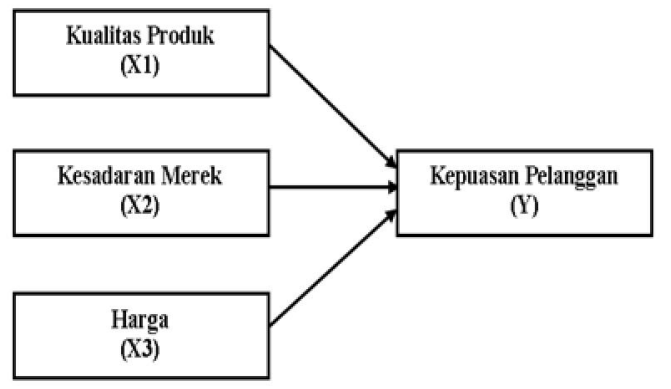

Gambar 1. Kerangka Konseptual

\section{Hipotesis Penelitian}

Penelitian ini menetapkan empat hipotesis untuk dijawab di penelitian ini. Empat hipotesis tersebut adalah: (a) kualitas produk memiliki pengaruh yang signifikan terhadap kepuasan pelanggan (b) kesadaran merek memiliki pengaruh yang signifikan terhadap terhadap kepuasan pelanggan; (c) harga memiliki pengaruh yang signifikan terhadap kepuasan pelanggan; (d) kualitas produk, kesadaran merek dan harga memiliki pengaruh simultan yang signifikan terhadap kepuasan pelanggan.

\section{Metode}

Analisis deskriptif kualitatif dengan penelitian eksplanatory research adalah teknik analisis data yang ditetapkan pada penelitian ini. Pengujian dilakukan dengan menggunakan SPSS 24. Teknik untuk mengambil sampel digunakan teknik non probability sampling dengan metode accidental sampling. Tempat penelitian di Kota Jombang. Objek yang diamati adalah Rumah makan Dewi Kahyangan ini terletak di Jl.dr. Soetomo Kabupaten Jombang. Populasi dari penelitian ini adalah pengunjung dan pelanggan rumah makan Dewi Kahyangan yang mengkonsumsi produk dari Dewi Kahyangan. Menurut Roscoe (1975), data minimal 50 sampel. Penelitian ini melibatkan 100 responden melalui pengumpulan data dari menyebar kuesioner dan survei. Responden yang terlibat pada penelitian ini yaitu pelanggan yang telah mencoba produk dari rumah makan Dewi Kahyangan. Item pernyataan yang digunakan berdasarkan variabel penelitian yang telah ditetapkan, yaitu kualitas produk, kesadaran merek, harga, dan kepuasan pelanggan. Tujuan dasar penelitian ini yaitu untuk mengetahui bagaimana responden memberikan pendapat terhadap kualitas produk, kesadaran merek, harga dan kepuasan pelanggan. Pernyataan-pernyataan disusun berdasarkan kisi-kisi menggunakan skala likert dengan 8 skala, yaitu (sangat setuju sekali, setuju sekali, setuju, agak setuju, kurang setuju, tidak setuju, tidak setuju sekali, sangat tidak setuju sekali). Hasil dari pengumpulan data akan diuji validitas dan reliabilitas serta melalui uji asumsi klasik dan uji hipotesis.

\section{Hasil}

Analisa hasil penelitian dimulai dengan memeriksa skala pengukuran, pada penelitian ini yang akan digunakan untuk analisis regresi melalui program SPSS 24. Pengujian uji reliabilitas menurut Hair et al. (2006), uji reliabilitas dilakukan dengan melihat nilai Cronbach alpha $(\alpha)$. Item pernyataan dari variabel dinyatakan reliabel bila nilai alpha ( $\alpha$ ) lebih besar dari 0,6 yang menunjukkan bahwa skala pengukuran untuk analisis adalah diterima atau dapat dihandalkan. Berdasarkan hasil perhitungan dengan menggunakan SPSS diperoleh hasil seperti pada Tabel 1.

Tabel 1 Hasil Uji Reliabilitas

\begin{tabular}{lcc}
\hline \multicolumn{1}{c}{ Variabel } & $\begin{array}{c}\text { N of } \\
\text { item }\end{array}$ & $\begin{array}{c}\text { Cronbach's } \\
\text { Alpha }\end{array}$ \\
\hline Kualitas produk & 16 & 0,895 \\
\hline Kesadaran merek & 6 & 0,805 \\
\hline Harga & 8 & 0,767 \\
\hline Kepuasan pelanggan & 10 & 0,792 \\
\hline Sumber: hasil olah SPSS &
\end{tabular}

Dari Tabel 1 dapat diketahui bahwa hasil uji reliabilitas menunjukkan: (1) nilai cronbach's alpha kualitas produk sebesar 0,895 . Enam belas pernyataan dinyatakan reliabel; (2) nilai cronbach's alpha kesadaran merek sebesar 0,805. Enam pernyataan dinyatakan reliabel; (3) nilai cronbach's 
alpha harga sebesar 0,767. Delapan pernyataan dinyatakan reliabel; (4) nilai cronbach's alpha kepuasan pelanggan sebesar 0,792 . Sepuluh pernyataan dinyatakan reliabel. Selanjutnya, untuk uji validitas semua item pernyataan dari masing-masing variabel memperoleh nilai Corrected ItemTotal Correlation lebih dari 0,3 sehingga dapat dinyatakan bahwa semua pernyataan adalah valid dan secara keseluruhan dapat dilanjutkan pada tahap uji asumsi klasik.

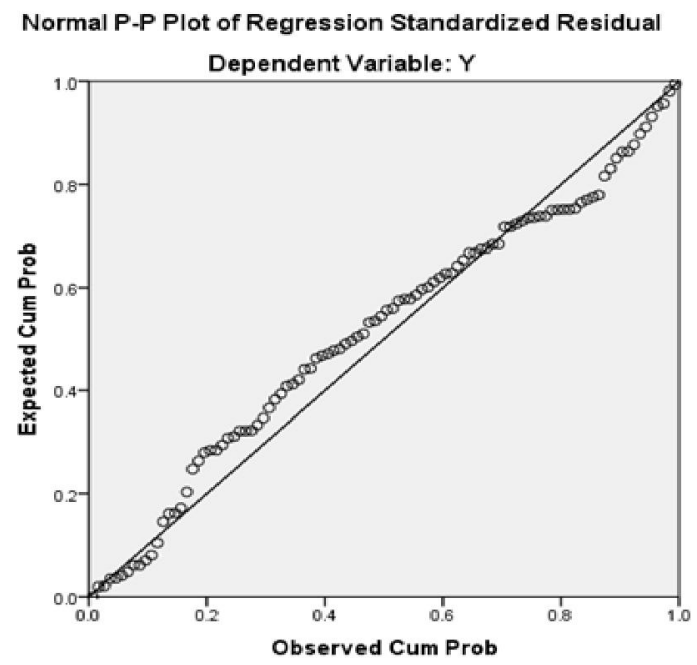

Gambar 2. Uji Normalitas

Uji heteroskedastisitas seperti pada Gambar 3 scatterplot pada dependent variable. Gambar tersebut menunjukkan bahwa titik-titik tersebar dan berada pada masing-masing bagian di sumbu Y. Dengan demikian dapat disimpulkan bahwa tidak terjadi heteroskedastisitas.

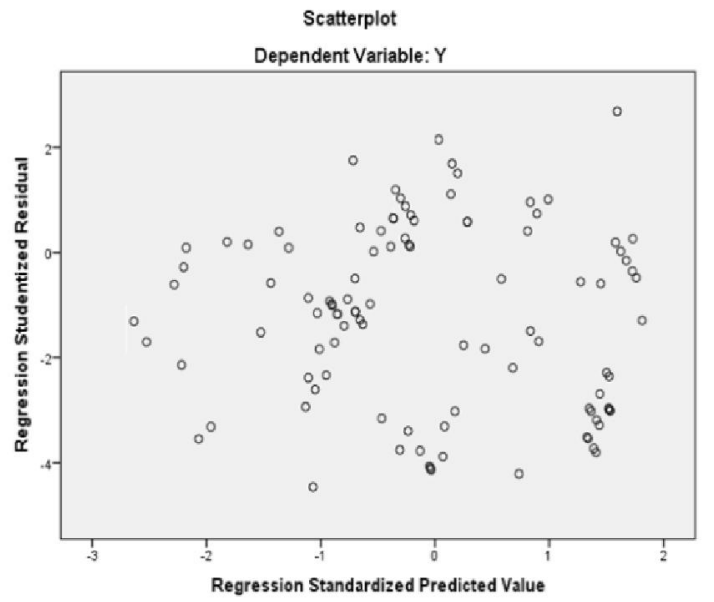

Gambar 3. Uji Heteroskedastisitas
Untuk uji asumsi klasik dilakukan pertama kali adalah uji normalitas seperti pada Gambar 2 yang menunjukkan sebaran data berada di sekitar garis diagonal dan dinyatakan data memiliki distribusi normal.

Uji autokorelasi diperoleh nilai 1,669. Uji Durbin Watson yang digunakan memperoleh nilai dengan rentang yang paling ideal untuk tidak terjadi autokorelasi antara 1,55 s.d 2,46. Dengan demikian tidak ada permasalahan pada uji autokorelasi.

Selanjutnya adalah uji hipotesis. Berdasarkan hasil perhitungan dengan menggunakan SPSS diperoleh hasil seperti pada Tabel 2 .

\begin{tabular}{lcrrrr} 
Tabel 2 Data Koefisien Regresi Linier Berganda & \\
\hline \multirow{2}{*}{ Model } & \multicolumn{2}{c}{$\begin{array}{c}\text { Unstandardized } \\
\text { Coefficients }\end{array}$} & $\begin{array}{c}\text { Std. } \\
\text { Coeff. }\end{array}$ & \multirow{2}{*}{$\mathrm{t}$} & \multirow{2}{*}{ Sig. } \\
\cline { 2 - 4 } & $\mathrm{B}$ & Std. Error & Beta & & \\
\hline Constant & 5.136 & 1.652 & & 3.109 & .002 \\
\hline $\mathbf{X 1}$ & .266 & .038 & .436 & 6.925 & .000 \\
\hline $\mathbf{X 2}$ & .442 & .084 & .312 & 5.273 & .000 \\
\hline $\mathbf{X 3}$ & .286 & .073 & .260 & 3.913 & .000 \\
\hline Sumber: Output SPSS & & & &
\end{tabular}

Dari hasil perhitungan tersebut seperti pada Tabel 2 maka hasil dari persamaan persamaan regresinya adalah:

$\mathrm{Y}=5,136+0,266\left(\mathrm{X}_{1}\right)+0,442\left(\mathrm{X}_{2}\right)+0,286\left(\mathrm{X}_{3}\right)$

Hipotesis yang menyatakan bahwa kualitas produk (X1) memiliki pengaruh signifikan terhadap kepuasan pelanggan $(\mathrm{Y})$ terbukti benar karena nilai $\operatorname{Sig} \mathrm{P}<0,05$ yaitu 0,000 . Nilai ini sama juga yang terjadi pada hipotesis kedua dan ketiga yang berhubungan dengan variabel kesadaran merek (X2) dan harga (X3). Dengan demikian kesadaran merek memiliki pengaruh signifikan terhadap kepuasan pelanggan serta harga memiliki pengaruh signifikan terhadap kepuasan pelanggan.

Selanjutnya dari hasil perhitungan sebelumnya, model persamaan regresi linier berganda menunjukkan bahwa adanya pengaruh antara kepuasan pelanggan (Y) sebagai variabel terikat dari variabel bebas kualitas produk (X1), kesadaran merek (X2) dan harga (X3). Pengaruh tersebut menunjukkan bahwa variabel kualitas produk, kesadaran merek dan harga sebagai 
variabel bebas berubah searah dengan perubahan kepuasan pelanggan sebagai variabel terikat.

\section{Tabel 3 Hasil Uji F}

\begin{tabular}{lrrrrr}
\hline \multicolumn{1}{c}{ Model } & $\begin{array}{c}\text { Sum of } \\
\text { Squares }\end{array}$ & df & $\begin{array}{c}\text { Mean } \\
\text { Square }\end{array}$ & F & Sig. \\
\hline Regression & 3430.704 & 3 & 1143.568 & 427.026 & $.000^{\mathrm{b}}$ \\
\hline Residual & 257.086 & 96 & 2.678 & & \\
\hline Total & 3687.790 & 99 & & & \\
\hline Sumber: Output SPSS & & & &
\end{tabular}

Uji serentak (Uji F) ini dilakukan dari hasil perhitungan data sebelumnya, dapat dilihat bahwa nilai $F_{\text {hitung }}$ sebesar 427.026 dengan probabilitas sebesar 0,000 , hal ini berarti bahwa pada taraf nyata $\alpha=0,05$ dapat dikatakan bahwa variabel bebas kualitas produk, kesadaran merek dan harga mempunyai pengaruh yang berarti terhadap kepuasan pelanggan pada rumah makan Dewi Kahyangan Jombang. Hipotesis di penelitian terbukti benar yang menyatakan bahwa kualitas produk, kesadaran merek dan harga berpengaruh signifikan secara simultan terhadap kepuasan pelanggan.

Tabel 4 Koefisien determinasi (R2)

\begin{tabular}{lccccc}
\hline Model & $\mathrm{R}$ & $\begin{array}{c}\mathrm{R} \\
\text { Square }\end{array}$ & $\begin{array}{c}\text { Adjuste } \\
\mathrm{d} \mathrm{R} \\
\text { Square }\end{array}$ & $\begin{array}{c}\text { Std. } \\
\text { Error of } \\
\text { the Est. }\end{array}$ & $\mathrm{DW}$ \\
\hline $\mathbf{1}$ & $.965^{\mathrm{a}}$ & .930 & .928 & 1.636 & 1.669 \\
\hline
\end{tabular}

Sumber: Output SPSS

Berdasarkan pada hasil penghitungan tersebut, koefisien $\mathrm{R}$ sebesar 0,965 menunjukkan adanya pengaruh yang cukup kuat antara variabel bebas dengan variabel terikat. Nilai Ajdust R Square sebesar 0,928 atau $92,8 \%$ artinya mempengaruhi semua variabel bebas: kualitas produk (X1), kesadaran merek (X2) dan harga (X3) terhadap variabel terikat kepuasan pelanggan (Y) sebesar 92,8\% dan sisanya sebesar 7,2\% dipengaruhi variabel lain.

\section{Pembahasan}

Hasil penelitian menunjukkan bahwa, kesadaran merek dan harga memiliki pengaruh positif yang signifikan terhadap kepuasan pelanggan. Hasilnya menunjukan bahwa kesadaran merek memiliki pengaruh yang lebih besar pada kepuasan pelanggan bila dibandingkan dengan kualitas produk dan harga. Kualitas produk memiliki pengaruh positif yang signifikan terhadap kepuasan pelanggan Pada hasilnya menunjukan bahwa kualitas produk memiliki pengaruh positif yang signifikan terhadap kepuasan pelanggan.

Hasil penelitian berdasarkan pembuktian hipotesis pertama menunjukkan bahwa kualitas produk memiliki pengaruh positif yang signifikan terhadap kepuasan pelanggan (Jahanshahi et al., 2011; Razak, 2016; Hoe dan Mansori, 2018). Dengan demikian pihak manajemen harus melakukan pendekatan TQM (Total Quality Manajemen) dimana ada keterlibatan dari seluruh pihak untuk meningkatkan kualitas produknya secara terus-menerus (Kotler dan Keller, 2009). Bagi kebanyakan rumah makan yang terkenal, salah satu cara untuk berbisnis yaitu dengan kulitas yang digerakkan oleh pelanggan. Seperti pada hasil temuan Santoso (2016) meningkatkan kualitas produk dianggap penting dengan memperhitungkan kesesuaian harga sehingga dapat berkompetisi yang sifatnya memperbaiki. Selain itu rumah makan yang memiliki kesan yang baik terhadap kualitas menurut persepsi konsumen akan memunculkan minat untuk mereferensikan rumah makan tersebut (Darmawan, 2002).

Hasil penelitian berdasarkan pembuktian hipotesis kedua menunjukkan bahwa kesadaran merek memiliki pengaruh positif yang signifikan dan memiliki pengaruh besar terhadap kepuasan pelanggan (Bilal dan Malik, 2014; Poranki, 2015). Manajemen harus terus menerus mengadakan investasi yang besar, penambahan keistimewaan baru dan peningkatan kualitas produk maupun layanan. Mereka seharusnya dapat mempertahankan program pemasaran yang menarik minat pelanggan baru dan mempertahankan kesadaran dan preferensi merek yang tinggi (Mardikaningsih dan Hakim, 2017). Melakukan bauran pemasaran seperti: (1) iklan, ketika menampilkan iklan secara berulang maka memiliki potensi untuk meningkatkan pelanggan memilih merek tersebut; (2) kategori produk dan promosi harga juga dapat membangun kesadaran merek (Huang dan Sarigollu, 2011). 
Hasil penelitian berdasarkan pembuktian hipotesis ketiga menunjukkan bahwa harga memiliki pengaruh positif yang signifikan terhadap kepuasan pelanggan (Malik et al., 2012; Bilal dan Malik, 2014; Foster, 2016). Pihak manajemen harus merencanakan penetapan harga secara tepat menurut kemampuan target pasar dan kesesuaian dengan nilai produk yang ditawarkan dengan perbandingan biaya dan manfaat menurut persepsi pembeli. Penetapan yang tepat memunculkan harga yang dapat diterima oleh pembeli dan bila dibuktikan dengan produk yang berkualitas dan layanan yang baik maka akan menimbulkan kepuasan konsumen pasca pembelian.

\section{Kesimpulan dan Saran}

\section{Kesimpulan}

Hasil penelitian menemukan bahwa (a) kualitas produk memiliki pengaruh signifikan terhadap kepuasan pelanggan; (b) kesadaran merek memiliki pengaruh signifikan terhadap kepuasan pelanggan; (c) harga memiliki pengaruh signifikan terhadap kepuasan pelanggan; dan (d) kualitas produk, kesadaran merek dan harga memiliki pengaruh signifikan secara simultan terhadap kepuasan pelanggan.

\section{Saran}

Hasil penelitian ini menyarankan kepada pihak rumah makan untuk meningkatkan kualitas produk dapat dimulai dengan mencari referensi dan ide baru untuk mengelola produk agar produk yang dihasilkan lebih beragam, ada suasana informal antara sekelompok pelanggan yang bertemu dengan manajer untuk mendiskusikan permasalahan, kebutuhan produk baru dan saling bertukar pendapat untuk mencapai solusi yang potensial, melakukan survei pelanggan yang dilakukan dengan mengevaluasi apa yang disukai atau tidak disukai dari produk yang telah dibeli dengan produk pesaing, memberikan beberapa survei pertanyaan kepada pelanggan dengan tujuan untuk memperbaiki dan mengevaluasi produknya, seperti (bagaimana pelanggan menggunakan produk tersebut, apakah produk yang dibeli memberikan permasalahan, bagaimana produk yang diinginkan pelanggan di masa depan), menyediakan situs web daring untuk menerima aspirasi dari para pelanggan dengan tujuan memperoleh umpan balik dan masukan, saran yang bermanfaat untuk tercapainya keberhasilan rumah makan di masa depan.

Rumah makan disarankan untuk meningkatkan kesadaran merek pihak rumah makan harus membuat konten penjualan yang menarik, relevan, memiliki nilai dan menciptakan brand experience untuk dapat membantu meningkatkan rasa percaya pelanggan terhadap kesadaran merek rumah makan tersebut, mengembangkan asosiasi merek yang positif dengan tujuan untuk memotivasi pelanggan memahami merek dari produk yang ditunjukkan, menampilkan iklan yang tepat dan nyata karena iklan yang efektif adalah salah satu cara yang dapat diterapkan untuk meningkatkan kesadaran merek dan mempengaruhi pelanggan baru. Iklan yang tepat dan nyata memberikan daya tarik tersendiri karena kredibilitasnya.

Pihak rumah makan harus mampu mempertahankan kesesuaian harga yang dikeluarkan pelanggan dengan manfaat yang diperoleh agar pelanggan dapat menjangkau harga yang telah ditetapkan atau disediakan oleh pihak rumah makan tersebut; dan (d) untuk penelitian selanjutnya disarankan melibatkan variabel bebas selain variabel yang telah diteliti seperti kualitas layanan, kepercayaan, persepsi manfaat, bauran pemasaran, citra perusahaan.

\section{Daftar Referensi}

Aaker, David Allen. 1997. Managing Brand Equity. Capitalizing on the Value of a Brand Name. New York. Free Press.

Ajzen, I., \& Fishbein, M. 1980. Understanding Attitudes and Predicting Social Behavior: Englewood Cliffs, New Jersey: Prentice-Hall.

Andaleeb, S. S., \& Conway, C. 2006. "Customer satisfaction in the restaurant industry: an examination of the 
transaction-specific model." Journal of Services Marketing, Vol. 20, No. 1, pp. 3-11.

Belohlav, J. A. 1993. "Quality, Strategy, and Competitiveness." California Management Review, Vol. 35, No. 3, pp. 55-67.

Benson, P.G., Saraph, J.V., \& Schroeder, R.G. 1991. "The Effects of Organizational Context on Quality Management: an Empirical Investigation." Management Science, September, pp.1107-24.

Berry, Leonard L. 2000. "Cultivating Services Brand Equity." Journal of the Academy of Marketing Science, Vol. 28, pp. 128-137.

Bhattacharya A. \& Friedman H. H. 2001. "Using "Smart" Pricing to Increase Profits and Maximize Customer Satisfaction". The National Public Accountant, Vol. 46 (6), pp. 34-37.

Bilal, Atif \& Faiza Majid Malik. 2014. "Impact Of Brand Equity \& Brand Awareness on Costumer Satisfaction". International Journal of Modern Management \& Foresight. Vol. 1, (10) Published on October, pp. 287-303

Bilgili, B., \& Ozkul, E. 2015. "Brand Awareness, Brand Personality, Brand Loyalty and Consumer Satisfaction Relations in Brand Positioning Strategies (A Torku Brand Sample)." Journal of Global Strategic Management, Vol. 9, No. 2, pp. 89-106.

Bolton, Ruth N. 1998. "A Dynamic Model of the Duration of the Customer's RelationshipWith a Continuous Service Provider: The Role of Satisfaction." Marketing Science, Vol. 17, No. 1, pp. 45-65.

Carr, L. P. 1995. Cost of Quality Making it Work. Journal of Cost Management, Vol. 9, No. 1, pp. 61-65.
Černikovaite, M. 2011. "Brand Value Measurement Models." Social Science Studies, Vol. 3, No. 3, pp. 967-981.

Chaudhuri, A. 2002. "How Brand Reputation Affects the Advertising Brand Equity Link?". Journal of Advertising Research, Vol.42 (3), pp. 33-43

Darmawan, Didit. 2002. Dampak Kesan Kualitas Rumah Makan terhadap Minat Mereferensikan. JEB's Jurnal Bisnis, Ekonomi dan Sosial, Vol. 3 No, 1, pp. 1 $-12$

Darmawan, Didit. 2014. Perilaku Konsumen. Metromedia, Surabaya.

Deng, Z., Lu, Y, Wei, K. K., Zhang, J. 2009. "Understanding customer satisfaction and loyalty: An empirical study of mobile instant messages in China." International Journal of Information Management, Vol. 30, pp. 289-300.

Dodds, W.B., Monroe, K.B., \& Grewal, D. 1991. "Effects of Price, Brand, and Store Information on Buyers Product Evaluations." Journal of Marketing Research, Vol. 28, No. 3, pp. 307-319.

Eduardo, T. M., Arturo, Z. V. P., \& Forge, Z. G. 2008. "Customer Satisfaction and Loyalty: Start with the product, culminate with the brand." Journal of Consumer Marketing, Vol. 25, No. 5, pp. 302-313.

Eid, M. I. 2011. Determinants of ECommerce Customer Satisfaction, Trust, and Loyalty in Saudi Arabia." Journal of Electronic Commerce Research, Vol. 12, No. 1, pp. 78-93.

Ekhveh, A \& Darvishi, A.Z. 2015. "The Impact of Brand Awareness on Repurchase Intention of Customers With Trilogy of Emotions Approach (Case Study for Cell Phones)." Applied mathematics in Engineering, Management and Technology, Vol. 3, No. 4, pp. 25-30. 
Farhana, Mosarrat. 2012. "Brand Elements Lead to Brand Equity: Differentiate or Die. " Information Management and Business Review, Vol. 4, No. 4, pp. 223233.

Farris, P. W., Bendle, T. N., Pfeifer, P. E., \& Reibstein, D. J. 2010. Marketing Metrics: The Definitive Guide to Measuring Performance. Upper Saddle River, New Jersey: Pearson Education, Inc.

Fetscherin, M., \& Toncar, M. F. 2009. "Valuating Brand Equity and ProductRelated Attributes in the Context of the German Automobile Market." Journal Of Brand Management, Vol. 17, No. 2, pp. 134-145.

Flavio, C. F., Filho, M. G., \& Bonney, M. 2009. "A Proposal for Integrating Production Control and Quality Control." Industrial Management \& Data Systems, Vol. 109, No. 5, pp. 683707.

Flynn, B. B., Schroeder, R. G., \& Sakakibara, S. 1995. "The Impact of Quality Management Practices on Performance and Competitive Advantage." Decision Sciences, Vol. 26, No. 5, pp. 659-692.

Flynn, B.B., Schroeder, R.G., \& Sakakibara, S 1994. "A Framework for Quality Management Research and An Associated Measurement Instrument." Journal of Operations Management, March, pp.339-66.

Foster, Bob. 2016. "The Effect of Price and Service Quality on Customer Satisfaction in Mutiara Hotel Bandung”. American Research Journal of Humanities and Social Sciences. Vol 12, pp. 1-12.

Garvin, David A. 1987. Managing Quality. New York. The Free Press.

Ha, J., \& Jang, S. 2010. "Effects of Service Quality and Food Quality: The moderating role of atmospherics in an ethnic restaurant segment." International Journal of Hospitality Management, Vol. 29, No. 3, pp. 520529.

Hair, Joshep F., Rolph E. Anderson, Ronald L. Tahtam \& W. C. Back. 2006. Multivariate Data Analysis. $6^{\text {th }}$ Edition. New Jersey. Pearson Educational, Inc.

Hilgenkamp, H., \& Shanteau, J. 2010. "Functional Measurement Analysis of Brand Equity: Does Brand Name Affect Perceptions of Quality?. Psicologica." International Journal of Methodology and Experimental Psychology, Vol. 31, No. 3, pp. 561-575.

Hoe, Ling Che., \& Shaheen Mansori,. 2018. "The Effects of Product Quality on Customer Satisfaction and Loyalty: Evidence from Malaysian Engineering Industry." International Journal of Industrial Marketing, Vol. 3, No. 1, pp. 20-35.

Hoeffler, S. \& Keller, K. L. 2002. "Building Brand Equity Through Corporate Societal Marketing." Journal of Public Policy \& Marketing, Vol.21, No. 1, pp. 78-89.

Hoffman, D. L., \& Fodor, M. 2010. "Can you measure the ROI of your social media marketing?." MIT Sloan Management Review, Vol. 52, No. 1, pp. 41-49.

Hogan, John E., Donald R. Lehman, Maria Merion, Rajendra K. Srivastava, Jacquelyn S. Thomas \& Peter C. Verhoef. 2002. "Linking Customer Assets to Financial Performance." Journal of Services Research, Vol. 5, Iss. 1, pp. 26-38.

Homburg, CH.; Klarmann, M., \& Schmitt, J. 2010. "Brand Awareness in Business Markets: When is it related to firm performance?" Internantional Journal of Research in Marketing, No. 27, pp. 201-212. 
Hoyer, D. W., \& Brown, S. P. 1990. "Effects of Brand Awareness on Choice for a Common, Repeat-Purchased Product." Journal of Consumer Research, Vol. 17, No. 2, pp. 141-148.

Huang R., \& Sarigollu, E. 2011. "How Brand Awareness Relates to Market Outcome, Brand Equity, and the Marketing Mix." Journal of Business Research, Vol. 65, No. 12, pp. 92-99.

Huber, F., Herrmann, A., \& Wricke, M. 2001. "Customer Satisfaction as an Antecedent of Price Acceptance, Results of an Empirical Study". Journal of Product \& Brand Management. Vol.10 (3), pp. 160-169.

Hui, E. C., \& Zheng, X. 2010. "Measuring Customer Satisfaction of FM Service in Housing Sector." A Structural Equation Model Approach. Facilities, Vol. 28, No. 5, pp. 306-320.

Hunt, H.K. 1977. Conceptualization and Measurement of Consumer Satisfaction and Dissatisfaction, Marketing Science Institute, Cambridge: MA.

Jahanshahi, A. A., Gasthi, M. A. H., Midarmadi, S. A., Nawaser, K., \& Khaksar, S. M. S. 2011. "Study the Effects of Customer Service and Product Quality on Customer Satisfaction and Loyalty." International Journal of Humanities and Social Science, Vol. 1, No. 7, pp. 253-260.

Khan, N. A. 2011. "A Study of Brands in the Food and Beverages Industry of Pakistan. International Journal of Business and Social Science, Vol. 2, No. 13.

Kotler, Philip \& Gary Armstrong. 2012. Prinsip-prinsip Pemasaran. Edisi 13. Jilid 1. Jakarta. Erlangga.

Kotler, Philip \& Kevin Keller. 2009. Manajemen Pemasaran. Jilid 1. Edisi 11. Jakarta. Terjemahan oleh Pearson Education Asia dan Prenhalindo.
Malik, Muhammad, Ehsan, Muhammad Mudasar Ghafoor \& Hafiz Kashif Iqbal. 2012. "Impact of Brand Image, Service Quality and Price on Customer Satisfaction in Pakistan Telecommunication Sector". International Journal of Business and Social Science. Desember Vol.3, No.23, pp.123-129.

Mardikaningsih, Rahayu \& Yusuf Rahman Al Hakim. 2017. Manajemen Bisnis Ritel, Metromedia, Surabaya.

Margee, Hume., \& Mort, G.S. 2008. "Satisfaction in Performing Arts: The role of value?." Eur. J. Mark, Vol. 42, pp. 311-326.

Mattila, A., \& O'Neill, J. 2003. "Relationships between Hotel Room Pricing, Occupancy, and Guest Satisfaction: A Longitudinal Case of a Midscale Hotel in the United States." Journal of Hospitality \& Tourism Research, Vol. 27, No. 3, pp.328-341.

Mcdonald, E.K., \& Sharp, B.M. 2000. Brand Awareness Effects on Consumer Decision Making for a Common, Repeat Purchase Product: A Replication. Journal of Business Research, Vol. 48, pp. 5-15.

Namkung, Y., \& Jang, S., 2007. "Does food quality really matter in restaurant: its impact of customer satisfaction and behavioral intentions?." Journal of Hospitality and Tourism Research, Vol. 31, No.3, pp. 387-410.

Ndukwe, G. I. 2011. "The Effect of Product Quality on Brand Loyalty." A Study of MTN.

Oliver, R. L. 1980. "A Cognitive Model of the Antecedents and Consequences of Satisfaction Decisions." Journal of Marketing Research, Vol. 17, pp. 460469. 
Oliver, R. L. 1997. Satisfaction: A behavioral perspective on the consumer, New York: McGraw Hill.

Oliver, R.L., \& William, O. B. 1983. "The Role of Involvement in Satisfaction Processes." Advances in Consumer Research, Vol. 10, pp. 250-255.

Percy, Larry \& Rossiter, John R. 1992. “A Model of Brand Awareness and Brand Attitude Advertising Strategies." Psychology \& Marketing, Vol. 9, No. 4, pp. 263-274.

Poranki, Kameswara Rao. 2015. "The Impact of Brand Awareness on Customer Satisfaction: A Case Study of Godfrey Phillips India Limited, India." The International Journal Publications Research Journal of Social Science dan Management, Vol. 05, No. 1, pp. 38-44.

Pryor, J. B., \& Kriss, M. 1977. "The Cognitive Dynamics of Salience in the Attribution Process." Journal of Personality and Social Psychology, Vol. 35, pp. 49-55.

Qin, H., \& Prybutok, V. R. 2009. "Service Quality, Customer Satisfaction, and Behavioral Intentions in Fast-Food Restaurants." International Journal of Quality and Service Sciences, Vol. 1, No. 1, pp. 78-95.

Ranaweera, C. \& Neely A. 2003. "Best student paper. Some Moderating Effects On The Service Quality-Customer Retention Link". International Journal of Operations \& Production Management. Vol. 23, No. 2, pp. 230248.

Razak, Ismail. 2016. "The Impact of Product Quality and Price on Customer Satisfaction with the Mediator of Customer Value". Journal of Marketing and Consumer Research, Vol.30, pp.5968.

Roscoe, John T. 1975. Fundamental Research Statistics for the Behavioral
Sciences. New York. Holt. Rinehart and Winston, Inc. pp. 189-197.

Rossiter, J.R. \& Percy, L. 1987. Advertising and Promotion Management. Singapore: McGraw Hill.

Ryu, K., Lee, H. K., \& Woo, G. 2012. "The Influence of the Quality of the Physical Environment, Food, and Service on Restaurant Image, Customer Perceived Value, Customer Satisfaction, and Behavioral Intentions." International Journal of Contemporary Hospitality Management, Vol. 24, No. 2, pp. 200223.

Salancik, G. R. \& Conway, M. 1975. "Attitude Inferences from Salient and Relevant Cognitive Content about Behavior." Journal of Personality and Social Psychology, Vol. 32, pp. 829840.

Saleh, J. H. 2008. "Analysis of Marginal Cost of Durability and Cost Per Day: A first step towards a rational choice of durability." Journal of Engineering Design, Vol. 19, No. 1, pp. 55- 74.

Santoso, Imam. 2016. "Peran Kualitas Produk dan Layanan, Harga dan Atmosfer Rumah Makan Cepat Saji terhadap Keputusan Pembelian dan Kepuasan Konsumen". Jurnal Manajemen Teknologi, Vol.15, No.1, pp. 94-109.

Santouridis, I., \& Trivellas, P. 2010. "Investigating the Impact of Service Quality and Customer Satisfaction on Customer Loyalty in Mobile Telephony in Greece. The TQM Journal, Vol. 22, No. 3, pp. 330- 343.

Smith, R. E., \& Wright, W.F. 2004. "Determinants of Customer Loyalty and Financial Performance" Journal of Management Accounting Research, Vol. 16, pp. 183-205.

Soderlund, M. 2000. I Huvudet Pa Kunde. Malmo. Liber Ekonomi. 
Srinivasan, V., Park, C. S., \& Chang, D. R. 2005. "An Approach to the Measurement, Analysis, and Prediction of Brand Equity and its Sources." Management Science, Vol. 51, No. 9, pp. 1433-1448.

Tellis, G. J., Y. Yin., \& R. Niraj. 2009b. "Reply to Comments: Why and how quality wins over network effects and what it means." Journal of Marketing Research, Vol. 46 , No. 2, pp. 150-62.

Tellis, G.J., Yin, Y., \& R. Niraj. 2009a. "Does quality win? Network effects versus quality in high-tech markets." Journal of Marketing Research, Vol. 46, No. 2, pp. 135-49.

Varki, S., \& Colgate, M. 2001. The Role of Price Perceptions in an Integrated Model of Behavioral Intentions. Journal of Service Research, Vol. 3, No. 3, pp. 232-240.

Verhoef, P. C., \& Lemon, K. C. 2013. "Successful Customer Value Management: Key Lessons and Emerging Trends." European Management Journal, Vol. 31, pp. 1-15.

Walter, A., Mueller, T. A., \& Helfert, G. 2002. "The Impact of Satisfaction, Trust, and Relationship Value on
Commitment: Theoretical

Considerations and Empirical Results."

Westbrook, Robert A., \& Richard, L. Oliver. 1981. Developing Better Measures of

Consumer Satisfaction: Some

Preliminary Results, Advances in Consumer Research, pp.8.

Wolf, F. M. 1986. Meta-Analysis: Quantitative Methods for Research Synthesis -Quantitative Applications in the Social Sciences. Thousand Oak, CA: Sage Publications.

Xu, H., Leung, A., \& Yan, R. 2013. "It is Nice to be Important, but it is More Important to be Nice: Country-oforigin's Perceived Warmth in Product Failures." Journal of Consumer Behavior, Vol. 12, No. 4, pp. 285-292.

Yuen, E. F. T., \& Chan, S. S. L. 2010. "The Effect of Retail Service Quality and Product Quality on Customer Loyalty." Journal of Database Marketing \& Customer Strategy Management, Vol. 17, pp. 222-240.

Zeithmal, V.A. 1996. "The Behavioral Consequences of Service Quality." Journal of Marketing, Vol. 60, No.2, pp. 31-46. 